\title{
Protodolomite: structure and formation in lakes
}

\author{
MIHÁLY PÓSFAI ${ }^{1}$, MR. ZSOMBOR MOLNÁR ${ }^{1}$, PÉTER \\ PEKKER $^{1}$, KORNÉL RÁCZ ${ }^{1}$, ISTVÁN DÓDONY ${ }^{1}$, IVETT \\ PÁLFI $^{2}$, FERENC KRISTÁLY $^{3}$, PATRICK MEISTER ${ }^{4}$, \\ SILVIA FRISIA $^{5}$ AND ENIKÖ MAGYARI $^{2}$ \\ ${ }^{1}$ University of Pannonia \\ ${ }^{2}$ Eötvös Loránd University \\ ${ }^{3}$ University of Miskolc \\ ${ }^{4}$ University of Vienna \\ ${ }^{5}$ University of Newcastle \\ Presenting Author: mihaly.posfai@gmail.com
}

The term 'protodolomite' was coined for describing rhombohedral carbonates that deviate from the composition of dolomite but possess some degree of cation order as seen from the presence of order reflections in XRD patterns [1,2]. However, the term was later also used for carbonates with dolomite-like composition but no ordering of $\mathrm{Ca}$ and $\mathrm{Mg}$ [3]. Protodolomite occurs in lake sediments [4,5], but is unclear whether it precipitates directly from solution, and its structural details are not always known.

We found protodolomite as ubiquitous in both sediments and suspended particles in two large, shallow, Mg-rich lakes in Central Europe (Lake Balaton and Neusiedlersee). In Neusiedlersee (dissolved $\mathrm{Mg} / \mathrm{Ca}>7$ ) the compositional range of carbonates is continuous from low-Mg calcite to that of dolomite. By contrast, in Lake Balaton $(1<\mathrm{Mg} / \mathrm{Ca}<5)$ carbonates show two distinct compositions, one corresponding to low-Mg calcite and the other to Ca-rich dolomite (protodolomite). Both the pattern of occurrence of protodolomite in suspended matter, mirroring the high $\mathrm{Mg} / \mathrm{Ca}$ ratios of the lake water, and its abundance within two distinct layers in the sediment of Lake Balaton (5500 and 8100 years BP), suggest that this material, possibly, precipitates directly from solution [6].

Our TEM analyses show that protodolomite from both lakes consists of few-nm-large domains that have highly variable degrees of $\mathrm{Mg} / \mathrm{Ca}$ ordering (in agreement with [5]). According to geometric phase analysis of high-resolution images, the domains have indistinct, strain-free boundaries. By using dark-field STEM imaging the variation of $\mathrm{Mg}$ content in individual atomic columns was analyzed. Dolomite-like ordering occurs even in particles with $\mathrm{Mg} / \mathrm{Ca}$ ratios as low as 0.5 . Although the protodolomite-rich bulk sediment samples yielded dolomite-type order reflections in XRD patterns, TEM observations show that ordering varies at the nm scale, and even domains characterized by dolomite-like periodicity are imperfectly ordered.

[1] Graf \& Goldsmith (1956), J. Geol. 64, 173-186. [2] Gaines (1977), J. Sed. Petrol. 47, 543-546. [3] Rodriguez-Blanco et al. (2015), Amer. Mineral. 100, 1172-1181. [4] Müller G. (1970), Nature 226, 749-750. [5] Fang and Xu (2019), J. Sed. Res. 89, 537-551. [6] Fussmann et al. (2020), Biogeosciences 17, 2085 2106. 